\title{
DEVELOPMENT OF VALIDATED HPTLC METHOD FOR QUANTIFICATION OF TRAZODONE IN HUMAN SERUM
}

\author{
SIGRID MENNICKENT ${ }^{\text {I*; }}$ ANA GONZÁLEZ ${ }^{1}$; MARIO VEGA ${ }^{2}$; GISELA RÍOS ${ }^{2}$; MARTA DE DIEGO ${ }^{1}$ \\ ${ }^{I}$ Department of Pharmacy, Faculty of Pharmacy, University of Concepción, P.O.Box 237, Concepción, Chile. \\ ${ }^{2}$ Department of Food Technology/Science, Faculty of Pharmacy, University of Concepción, P.O.Box 237, Concepción, Chile.
}

\begin{abstract}
A high performance thin-layer chromatographic (HPTLC) method for quantitative analysis of trazodone in human serum has been developed and validated. Trazodone was extracted with n-hexane: isoamyl alcohol (99:1). Chromatographic separation was performed on silica gel $60 \mathrm{~F} 254 \mathrm{HPTLC}$ plates, with toluene: acetone: ethanol: ammonium (9:7:2:0.5, v/v/v/v) as mobile phase. Densitometric evaluation was carried out at $290 \mathrm{~nm}$. There was no chromatographic interference between trazodone and its major metabolite, $m$-chlorophenilpiperazine $\left(\mathrm{R}_{\mathrm{f}} 0.82\right.$ and 0.39 , respectively). Regression analysis of the calibration plot revealed good linearity $(\mathrm{r}=0.999)$ over the range of 20.00 and $200.00 \mathrm{ng} / \mathrm{band}$, corresponding to 0.20 and $2.00 \mathrm{ng} / \mu \mathrm{L}$ of trazodone in human serum after extraction process and applying $10 \mu \mathrm{L}$ to the chromatographic plates. The $\%$ RSD of intra-assay and inter-assay precision, were in the range of $0.98 \%$ to $2.97 \%$ (n=3) and $1.06 \%$ to $3.54 \%$ $(\mathrm{n}=9)$, respectively. LOD and LOQ were found to be $0.016 \mathrm{ng} / \mu \mathrm{L}$, and $0.048 \mathrm{ng} / \mu \mathrm{L}$, and the recovery values, of trazodone from serum, were between $92.52 \%$ and $96.73 \%$. This method was successfully applied to quantify trazodone in patient serum samples. In conclusion, the developed method might be useful for the quantitative determination of trazodone in human serum, as a tool to evaluate patient adherence to their pharmacotherapy with this drug.
\end{abstract}

Key words: Trazodone, HPTLC, quantitative analysis, serum, drugs.

\section{INTRODUCTION}

Trazodone (Figure 1) is a FDA approved orally antidepressant drug that is chemically and structurally unrelated to tricyclic or tetracyclic antidepressants or to selective serotonin-reuptake inhibitors. ${ }^{1}$

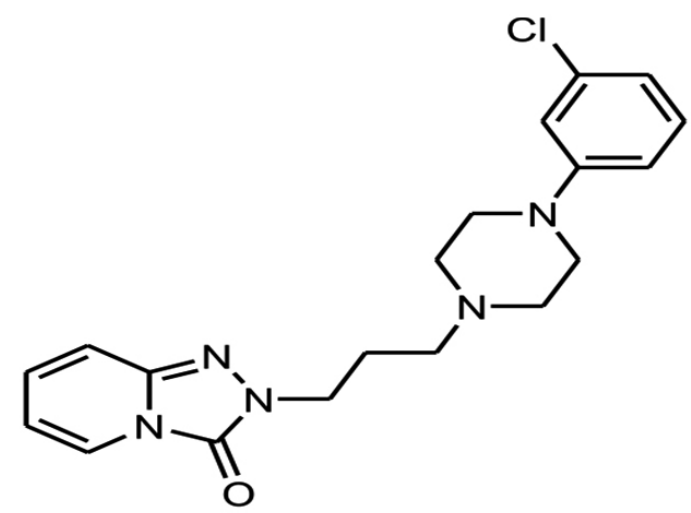

Figure 1. Chemical structure of trazodone.

Trazodone is used in the treatment of major depressive disorder, specially in patients who exhibit a prominent and realively persistent depressed or dysphoric mood that usually interferes with daily functioning. Moreover, trazodone is used in patients with major depression who have associated anxiety. ${ }^{1-3}$

Trazodone is rapidly and almost completely absorbed from the gastrointestinal tract following oral administration. Peak plasma concentrations of trazodone occur approximately 1 hour after oral administration when the drug is taken on an empty stomach or two hours after oral administration when taken with food.

Trazodone is extensively metabolized in the liver, and its major and active metabolite is $m$-chlorophenilpiperazine.

The usual range encountered in patients treated with the drug, is between $0.48-1.62 \mathrm{ng} / \mu \mathrm{L} .^{1-3}$

Patient's adherence to antidepressant drug regimen is an important factor in achieving the recovery of the patients and reducing outcomes. Between 30 and $83 \%$ of patients discontinue their therapy prematurely. Non-adherence to treatment increases medical charges, familiar, personal and social costs. ${ }^{4-10}$

There are two ways to evaluate pharmacotherapy adherence of the patients: indirect methods, as questionnaires about the daily administration of the drug, and pill counts, with the problem that the results can be true or false ${ }^{11-14}$; or by a direct method, the determination of drug levels in biological fluids. ${ }^{1-3} \mathrm{Hepatic}$ or renal damage are related with a lower drug excretion and, therefore, with higher plasmatic concentrations. Therefore, these patients must be excluded from the study.

After optimal evaluation of the pharmacotherapy adherence, it can be improved with psychosocial interventions used in conjunction with pharmacotherapy.

Literature survey reveals that some $\mathrm{LC}^{15-23}$ and $\mathrm{GC}^{24}$ had been reported for the determination of trazodone in human blood in the last years. Also a HPTLC method ${ }^{25}$, but, although this HPTLC method was find, our work has important advantages, as its precision. Other significant advantage of our method is the sample application as band, better than application as spot. Moreover, the incorporate chamber developed to the system had give better results.

HPTLC allows for a fast analysis, because many samples can be analyzed simultaneously, with minor cost in solvents and time than other techniques, and with a very good selectivity, accuracy and reproducibility. Sensibility of HPTLC is in the order of nanograms or pictograms Authors have performed some works using HPTLC for quantitative determination of drugs in biological fluids ${ }^{26-29}$, and in dosage forms ${ }^{30-35}$ with exact and reliable results.

Therefore, the aim of the present work was to develop and validate a sensitive, accurate, precise, selective and fast HPTLC method for quantitative determination of trazodone in human serum. This should be useful for application in therapeutic drug monitoring of this drug and evaluation of the pharmacotherapy adherence.

\section{EXPERIMENTAL}

\section{Material}

Instrumentation

HPTLC system: TLC Scanner 3 (CAMAG, Muttenz, Switzerland), equipped with software winCATS 1.4.3 (CAMAG). Band application device: automatic TLC Sampler 3 (CAMAG); automatic chamber ADC2 (CAMAG); and HPTLC plates precoated with silica gel F 254 (Merck, Darmstadt, Germany). Reprostar 3, picture camera.

WLW Centrifuge (Germany), Heidolph shaker (Gemany), and Reacti-Vap evaporator (Rockford, USA). Brand Micropippetes.

\section{Reagents and chemicals}

USP standards of trazodone and $m$-chlorophenilpiperazine were obtained from Sigma- Aldrich, St.Louis, MO. N-hexane, isoamyl alcohol, toluene, acetone, ethanol, ammonium and methanol, were from Merck, Darmstadt, Germany. All of the reagents were pro-analysis quality. 


\section{Methods}

Drug solutions

Accuracely weighed trazodone standard was dissolved in methanol to get a concentration of $1 \mathrm{mg} / \mathrm{mL}$. Blank serum samples were spiked with standard solution, to obtain final concentrations of 0.20 to $2.00 \mathrm{ng} / \mu \mathrm{L}$ of trazodone.

Drug-free serum used for the validation of the method was obtained from healthy volunteers. Serum collected was stored at $-20^{\circ} \mathrm{C}$.

\section{Serum samples}

Blood of patient volunteers $(\mathrm{n}=5)$ who were using trazodone as treatment for major depression were used for quantitative determination of the drug from biological fluid. The collection of the samples was done in the morning, before the next drug administration. Blood was withdrawn from the antecubital vein Serum was separated from plasma by centrifugation of blood samples at 3000 $\mathrm{rpm}$ for ten minutes and, if not assayed on the same day, stored at $-20^{\circ} \mathrm{C}$ for two days.

\section{Extraction procedure}

$1 \mathrm{~mL}$ of $\mathrm{NaOH} 2.00 \mathrm{M}$ was added to $2 \mathrm{~mL}$ of serum in a glass-stoppered tube and vortexed. Then, $10 \mathrm{~mL}$ of $\mathrm{n}$-hexane - isoamyl alcohol $(99: 1, \mathrm{v} / \mathrm{v})$ was added to the solution, which was subsequently vortexed for 15 minutes and centrifuged for 5 minutes at $3000 \mathrm{rpm}$. The organic phase was transfer to another test tube, and then, evaporated under a gentle steam of dry nitrogen at $40^{\circ} \mathrm{C}$. The residue was dissolved in $200 \mu \mathrm{L}$ of methanol. An aliquot of $10 \mu \mathrm{L}$ of this solution was spotted for analysis. All the procedure was accomplished under safety conditions.

\section{Chromatography}

The samples were spotted in the form of bands of $4 \mathrm{~mm}$ bands width on silica gel F254 plates with a constant application of $0.1 \mathrm{~mL} / \mathrm{sec}$, using an automatic TLC Sampler 3 (CAMAG). The developed mobile phase was consisted of toluene: acetone: ethanol: ammonium (9:7:2:0.5, v/v/v/v). Linear ascending development was carried out in automatic ACD2 chamber (CAMAG). The migration distance was $8 \mathrm{~cm}$ and the migration time 10 minutes. Densitometry readings were carried out using a TLC Scanner 3 CAMAG assisted by a computer equipped with software winCATS 1.4.3, and a deuterium lamp was used as the radiation source. Densitometric scanning was performed at $290 \mathrm{~nm}$. The slit dimension was kept at $5 \mathrm{~mm} \times 0.45 \mathrm{~mm}$, and $10 \mathrm{~mm} / \mathrm{sec}$ scanning speed was employed. Each track was scanned thrice and baseline correction was used prior to integration.

\section{Validation}

Validation was performed in compliance with international guidelines ${ }^{36-39}$ using adequate statistics estimates.

\section{RESULTS AND DISCUSSION}

In an attempt to optimize the mobile phase, various mixtures of solvents were investigated. The use of toluene: acetone: ethanol: ammonium (9:7:2:0.5, $\mathrm{v} / \mathrm{v} / \mathrm{v} / \mathrm{v})$ resulted in sharp, well-defined peak. The optimum wavelength for detection and quantification was $290 \mathrm{~nm}$.

\section{Linearity (calibration plots)}

The standard curve of trazodone was linear over the concentration range of $0.20 \mathrm{ng} / \mu \mathrm{L}$ and $2.00 \mathrm{ng} / \mu \mathrm{L}(0.20 ; 0.50 ; 1.00 ; 1.50 ; 2.00 \mathrm{ng} / \mu \mathrm{L})$, which corresponded to $20 \mathrm{ng} / \mathrm{spot}$ and $200 \mathrm{ng} / \mathrm{band}$, respectively, after the extraction process and with application of $10 \mu \mathrm{L}$ each time to the chromatographic plates. Five different concentrations were used and each solution was spotted six times. This range includes the trazodone concentrations expected in serum (0.48 to $1.62 \mathrm{ng} / \mu \mathrm{L})$. $^{1-3}$

The equation of the standard curve relating the peak areas to the concentration of trazodone was: $\mathrm{y}=349.52 \mathrm{x}+57.21$ with a correlation coefficient of 0.999

\section{Detection and quantification limit}

The limit of detection (LOD) and limit of quantification (LOQ) were calculated preparing solutions at three concentrations $(0.05 ; 0.10 ; 0.15 \mathrm{ng} / \mu \mathrm{L})$ in the lower range of linear regression curve.

LOD was $0.016 \mathrm{ng} / \mu \mathrm{L}$ and LOQ was $0.048 \mathrm{ng} / \mu \mathrm{L}$, determined using the equations ${ }^{36-39}: \mathrm{LOD}=3.3 \mathrm{~s} / \mathrm{b} ; \mathrm{LOQ}=10 \mathrm{~s} / \mathrm{b}$, where $\mathrm{s}$ is the standard deviation of the responses, and "b" corresponds to the slope of the curve.

\section{Precision}

Precision of the method was evaluated by repeatability and intermediate precision studies.
Trazodone solutions of $0.20 \mathrm{ng} / \mu \mathrm{L}, 1.00 \mathrm{ng} / \mu \mathrm{L}$ and $2.00 \mathrm{ng} / \mu \mathrm{L}$ were used in these studies. Three solutions of each concentration were independently prepared and each of them being applied three times. ${ }^{36-39}$

For repeatability study, all applications were made on the same plate, by the same analyst, on the same instrument, and on the same day. To study the intermediate precision or inter-assay precision, solutions of each concentration were independently prepared for three different days. Precision analysis studies showed an intra-assay variation between $0.98 \%$ and $2.97 \%$ and an inter-assay variation (intermediate precision) between $1.06 \%$ and $3.54 \%$ (Table 1).

Table 1. Precision of the method.

\begin{tabular}{|c|c|c|}
\hline \multicolumn{3}{|c|}{ Relative standard deviation (RSD), \% } \\
\hline Concentration $(\mathrm{ng} / \mu \mathrm{L})$ & Intra-assay $^{\mathrm{a}}$ & Inter-assay $^{\mathrm{b}}$ \\
\hline 0.20 & 2.97 & 1.06 \\
\hline 1.00 & 1.54 & 2.35 \\
\hline 2.00 & 0.98 & 3.54 \\
\hline
\end{tabular}

${ }^{a} \mathrm{n}=3$; analyzed on the same day (three solutions of each concentration)

b $\mathrm{n}=9$; analyzed on three different days (three solutions of each concentration prepared for 3 days)

Accuracy

The accuracy of the method was determined by \%recovery, obtained from linear regression equation. Solutions of $0.20 \mathrm{ng} / \mu \mathrm{L}, 1.00 \mathrm{ng} / \mu \mathrm{L}$ and $2.00 \mathrm{ng} / \mu \mathrm{L}$ were used in this study. Three solutions of each concentration were independently prepared and each of them was applied three times. The recovery obtained was between $94.72 \%$ and $98.96 \%$, as show in Table 2 .

Table 2. Method accuracy.

\begin{tabular}{|c|c|c|c|}
\hline $\begin{array}{c}\text { Actual } \\
\text { concentration } \\
(\mathrm{ng} / \mu \mathrm{L})\end{array}$ & $\begin{array}{c}\text { Measured } \\
\text { concentration } \\
(\mathrm{ng} / \mu \mathrm{L})^{\mathrm{a}}\end{array}$ & Accuracy, ${ }^{\mathrm{b}}$ & $\mathrm{RSD}, \%$ \\
\hline \multicolumn{4}{|c|}{ Intra-assay $(\mathrm{n}=3)$} \\
\hline 0.20 & $0.19 \pm 0.006$ & 94.79 & 3.15 \\
\hline 1.00 & $0.97 \pm 0.002$ & 97.32 & 2.06 \\
\hline 2.00 & $1.97 \pm 0.034$ & 98.96 & 1.73 \\
\hline \multicolumn{4}{|c|}{ Inter-assay $(\mathrm{n}=9)$} \\
\hline 0.20 & $0.19 \pm 0.006$ & 94.72 & 3.16 \\
\hline 1.00 & $0.97 \pm 0.031$ & 6.89 & 3.20 \\
\hline 2.00 & $1.97 \pm 0.046$ & 98.32 & 2.33 \\
\hline
\end{tabular}

${ }^{a}$ Each value is the mean \pm standard deviation.

${ }^{\mathrm{b}}$ (Founded concentration/ added concentration) x 100.

Relative standard deviation.

\section{Extraction recovery}

The extraction recovery of trazodone from serum was evaluated using solutions of $0.20 \mathrm{ng} / \mu \mathrm{L}, 1.00 \mathrm{ng} / \mu \mathrm{L}$ and $2.00 \mathrm{ng} / \mu \mathrm{L}$. The extraction recoveries were calculated comparing the observed concentrations obtained from the processed standard samples to the concentrations obtained from the standards solutions added to the serum after the extraction, which represented $100 \%$ recovery. The extraction recovery of trazodone from serum ranged from 92.52 $\%$ to $96.73 \%$

\section{Selectivity}

The selectivity was evaluated by observing any interference from the main metabolite of trazodone ( $m$-chlorophenilpiperazine) and the parent compound.

The solutions were prepared at a concentration of $1.00 \mathrm{ng} / \mu \mathrm{L}$ of each compound.

No interferences were found between trazodone and its metabolite $\left(\mathrm{R}_{\mathrm{f}}=\right.$ 0.82 and 0.39 , respectively) (Figure 2). 


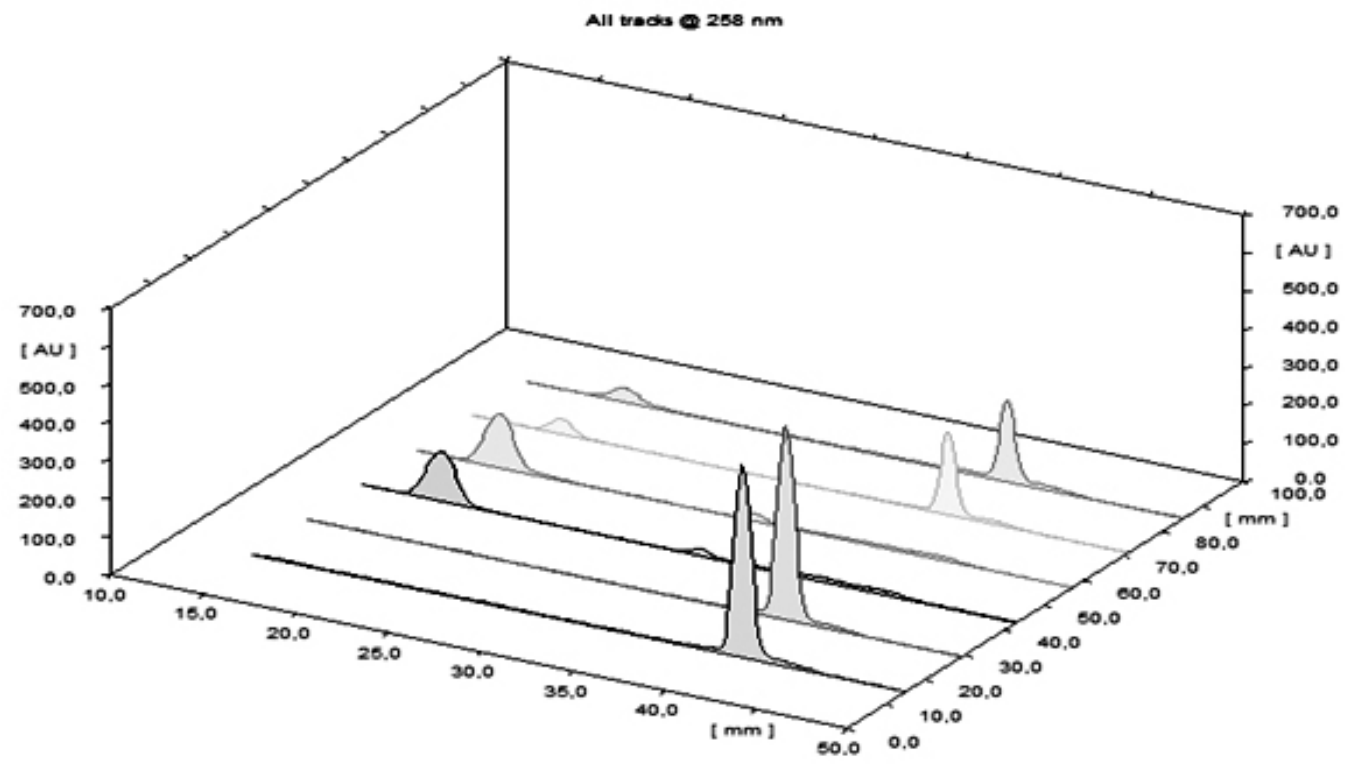

Figure 2. Selectivity between trazodone and its major metabolite ( $m$-chlorophenilpiperazine). Peak ${ }^{\circ} 1$ : metabolite; peak $\mathrm{n}^{\circ} 2$ : trazodone.

AU. Absorbance unit.

Also, samples of blank serum free of drug obtained from healthy volunteers were spoted. No peak was found, therefore, there are no inteferences between trazodone, its metabolite and blank serum.

\section{Application of the method}

This method was used to measure the concentration of trazodone in serum of volunteers patients $(n=5)$ who were using trazodone as pharmacotheraphy for major depression for at least six months. The collection of the samples was done in the morning, twelve hours after the last drug administration. The trazodone concentration ranged between $0.40 \mathrm{ng} / \mu \mathrm{L}$ and $1.50 \mathrm{ng} / \mu \mathrm{L} \quad(0.40$ $\mathrm{ng} / \mu \mathrm{L}, 051 \mathrm{ng} / \mu \mathrm{L}, 0.64 \mathrm{ng} / \mu \mathrm{L}, 0.86 \mathrm{ng} / \mu \mathrm{L}, 1.50 \mathrm{ng} / \mu \mathrm{L}$ ), with a standard deviation of 3.51 .

\section{Stability}

Stability of trazodone in the matrix of human serum was assessed by store solutions of $0.20 \mathrm{ng} / \mu \mathrm{L}, 1.00 \mathrm{ng} / \mu \mathrm{L}$ and $2.00 \mathrm{ng} / \mu \mathrm{L}$ at $-20^{\circ} \mathrm{C}$ for up to 12 weeks. Measurements were done at days: 0, 10, 20, 40, 60 and 84. Observed concentrations of trazodone during this time ranged between $92.65 \%-98.37 \%$.

Freeze-thaw stability of trazodone in human serum was studied using solutions exposed to three cycles of freezing-thawing versus regularly treated quality control samples. The measured concentrations of trazodone ranged between $93.70 \%$ and $98.25 \%$.

Comparison of results with other analytical methods to determination of trazodone in blood

This method has a better extraction recovery percentage and a better precision than other methods for quantitative determination of trazodone in blood ${ }^{15-25}$. The proposed method has extraction recoveries of trazodone from serum between $92.5 \%$ and $96.7 \%$, whereas the method by Okhubo et al ${ }^{19}$ showed extraction recoveries of $81.0 \%$ to $84.2 \%$, and the method of RaviPrakash et al ${ }^{16}$ had trazodone recoveries from blood between $36.1 \%$ and $40.8 \%$. The method by Li-Bo et al ${ }^{17}$ showed an extraction recovery of 72.6 $\%$ to $88.3 \%$, and with precision (RSD) of $2.9 \%$ to $3.7 \%$. The RSD for the precision studies of our method was between $1.0 \%$ and $3.5 \%$. Mercollini ${ }^{18}$ obtained a RSD for the method precision of $5.6 \%$, and Patel of $8.4 \%{ }^{23}$. All of these methods, except our method, were by LC. Siek ${ }^{25}$ obtained a RSD for precision studies of $3 \%$, by a HPTLC method.

\section{CONCLUSIONS}

The aim of this study was establish a simple HPTLC method suitable for quantification of trazodone in serum samples, method that can be used with easy-to-handle equipment for the therapeutic monitoring of serum levels, as a tool for evaluate patient adherence to their drug treatment.

HPTLC separation was obtained within ten minutes. This procedure enables the determination of trazodone using a very simple and fast liquidliquid extraction method, with a very good efficacy, having extraction recoveries between $92.5 \%$ and $96.7 \%$, better than other methods to quantify trazodone in blood ${ }^{15-25}$. The intra-day and inter-day variation of trazodone concentrations were in concordance with the precision criteria for an assay method for drugs in biological fluids ${ }^{36-39}$, and also were better than other methods to quantitative determination of trazodone in blood ${ }^{15-25}$. Serum levels of trazodone at therapeutically efective doses $(0.48-1.62 \mathrm{ng} / \mu \mathrm{L})^{1-3}$ are above the detection limit $(0.016 \mathrm{ng} / \mu \mathrm{L})$ and above the quantification limit $(0.048 \mathrm{ng}$ / $\mu \mathrm{L})$ for this method.

No interference was found between trazodone peak and metabolite peak.

The most significant advantages of the present HPTLC method are that the chromatographic conditions are simple, the analysis requires a short period of time, and the method allows a large number of samples to be measured simultaneously with a very good accuracy, sensitivity and precision.

\section{ACNOWLEDGMENTS}

The authors would like to thank the Research Council at the University of Concepción (Project nº 211.074.034-1.0).

\section{REFERENCES}

(1) J. Hardman, L. Limbird, Las Bases Farmacológicas de la Terapéutica, $M c$ Graw-Hill, México, (2003).

(2) G. Mc Evoy, AHFS Drug Information, American Society of HealthSystem Pharmacists, Bethesda, (2006).

(3) S. Sweetman, Martindale, Guía Completa de Consulta Farmacoterapéutica, Pharma Editores S.L, Barcelona, (2003).

(4) K. Demyttenaere, European-Neuropsychopharmacology, 13, 69, (2003).

(5) C. Thompson, R. Preveler, D. Stephenson, J. McKendrick, AJP. 157, 338, (2000).

(6) A. Vergouwen, A. Bakker, H. Burger, T. Verheij, F. Koerselman, Psychological Medicine. 35, 25, (2005).

(7) B. Sleath, K. Wurst, T. Lowery, Community Mental Health Journal. 39 , $359,(2003)$

(8) L. Van Dijk, E. Heerdink, D. Somai, S. van Dulmen, T. de Ridder, A. Griens, et al., BMC Health Service Research Journal . 7, 51, (2007).

(9) L. Osterberg, T. Blaschke, Curr. Drug Ther. 353, 487, (2005). 
(10) J.Hamman, N. Maris, P.Iosifidou, R. Mendel, R. Cohen, P. Wolf, et al., Int.J.Soc.Psichiatry. 3, 227, (2014).

(11) C.R. Cantrell, M.T. Eaddy,M.B. Shah,T.S. Regan, M.C. Sokol, Medical Care. 44, 300, (2006)

(12) J. Aikens,D. Nease,D., Nau,M. Klinkman, T. Schwenk, Ann Fam. Med. 3, 23, (2005).

(13) V. Jukic, Coll.Antropol. 27, 119, (2003).

(14) M. Sajatovic, C.H. Peijun, D.Philipp, S.Edwin, Disease Management/ Health Outcomes. 15, 181, (2007).

(15) A.s Di Tella, C. Di Nunzio, P. Ricci, G. Parisi, J Anal Toxicol. 10, 233, (1986).

(16) P.V.D.L.S. Ravi- Prakash, B. Sumadhuri, M. Srikanth, 2:650 doi:10.4172/ scientificreports.650.

(17) D. Li-Bo, R. Rong-Hua,L. Huan-De, W. Feng, F.Ping-Fej, L. Jiang, J.Chromatogr. B. 944, 43, (2014).

(18) L. Mercolini, C. Colliva, M. Amore, S. Fanali, M.A. Raggi, J.Pharm. Biomed.Anal. 47, 882, (2008).

(19) T.Ohkubo, T.Osanai, K.Sugawara, M. Ishida, K.Otani, K.Mihara, N.Yasui, J.Pharm. Pharmacol. 47, 340, (1995).

(20) G. Vatassery, L.A.Holden, D.K.Hazel, M.Dysken, Clin.Biochem. 30, 149, (1997).

(21) A. El-Gindy, B. El-Zeany, T.Awad, M.M.Shaban, J.Pharm.Biomed.Anal. 26, 211, (2001).

(22) G.Yang, P.Liu, X.Qu, M.Ming-Shen, C.Wang, Q.Qu, X.Hu, Z.Leng, Anal. Letters 40, 151, (2007).

(23) B.N.Patel, N.Sharma, M.Sanyal, P.Shrivastav, J. Chromatogr. B 871, 44, (2008).

(24) W.h. Anderson, M.M. Archuleta, J Anal Toxicol. 8, 217, (1984).
(25) T.J. Siek, J.Anal. Toxicol. 11, 225, (1987).

(26) S. Mennickent, A. Sobarzo, M. Vega, C.G. Godoy, M. de Diego, J. Sep. Sci., 30, 2167, (2007).

(27) S. Mennickent, M. Vega, C.G. Godoy, J. Chil. Chem. Soc. 48, 71, (2003).

(28) S. Mennickent, R. Fierro, M. Vega, M. de Diego, J. Sep. Sci. 32, 1454, (2009).

(29) S. Mennickent, A. Sobarzo, M. Vega, M. de Diego, C.G. Godoy, P. Rioseco, L. Saavedra, IJPCP. 14, 41, (2010).

(30) S. Mennickent, M. Vega, C.G. Godoy, T. Yates, Bol.Soc.Chil.Quim. 45, $615,(2000)$.

(31) S. Mennickent, T Yates, M. Vega, C.G. Godoy, R. Saelzer, Rev. Med. Chile. 130, 409, (2002).

(32) S. Mennickent, L. Pino, M. Vega, C.G. Godoy, M. de Diego, J. Sep. Sci. 30, 772, (2007).

(33) S.Mennickent, L. Pino, M. Vega, M. de Diego, J. Sep. Sci., 31, 201, (2007).

(34) S. Mennickent, M. Nail, M. Vega, M. de Diego, J.Sep.Sci. 30, 1893, (2007).

(35) S. Mennickent, J. Contreras, C. Reyes, M. Vega, M. de Diego, JPC. 23, $75,(2010)$

(36) The United States Pharmacopeia, $35^{\text {th }}$ ed. U.S. Pharmacopeial Convection Inc., Rockville, (2005).

(37) The Sixth ICH International Conference on Armonization of Technical Requirements for Registration of Pharmaceuticals for Human Use Osaka, Japan (2003).

(38) O. Quattrochi, S. Abelaira, R. Laba, R, Introducción a la HPLC: Aplicación y práctica. Artes Gráficas Farro, Buenos Aires (1992).

(39) G. Shabir, Journal of Chromatogr. A. 987, pp 57-66, (2003). 